\title{
Extension of flood basalt on the northwestern continental margin of India
}

\author{
P Kumar ${ }^{1,2}$ and A K Chauber ${ }^{1,2, *}$ \\ ${ }^{1}$ CSIR-National Institute of Oceanography, Regional Centre, Lokhandwala Road, Four Bunglow, Andheri (West), \\ Mumbai 400 053, India. \\ ${ }^{2}$ CSIR-National Institute of Oceanography, Academy of Scientific and Innovative Research, Goa 403 004, India. \\ *Corresponding author. e-mail: chaubey@nio.org
}

MS received 7 February 2018; revised 25 June 2018; accepted 25 June 2018; published online 22 March 2019

The Deccan Continental Flood Basalt (DCFB) in central western India is a large igneous province that covers almost one-sixth area of India. It is erupted in less than 1 million years during the magnetic chron $29 \mathrm{r}(\sim 65.6-64.8 \mathrm{Ma})$ through the Cretaceous-Tertiary boundary. It is believed that nearly an equivalent area of flood basalt, adjoining the DCFB, is submerged on the northwestern continental margin of India (NWCMI). Onshore information on the DCFB is widely reported in geological and geophysical studies. However, knowledge on the offshore extent of flood basalt is poorly known because of paucity of marine geophysical data and lack of an appropriate approach to determine the flood basalt. To fill this gap in knowledge, $\mathrm{P}$-wave velocity in flood basalt as a proxy, drilled wells results, and published seaward dipping reflectors are used to delineate flood basalt extent on the NWCMI. The results of the study reveal that $\mathrm{P}$-wave velocity in the flood basalt varies from 4.1 to $5.2 \mathrm{~km} / \mathrm{s}$. Apart from some isolated basement-high features, it is found that flood basalt lies below sediment and carpets the entire NWCMI extending up to the Laxmi-Laccadive ridges. The depth of occurrence of flood basalt ranges from 800 to $7400 \mathrm{~m}$, with a maximum thickness of $\sim 3900 \mathrm{~m}$ in the eastern part of the Laxmi basin. The article presents preliminary results about the extension of flood basalt on the western continental margin of India which may be useful for researchers and Indian oil industries planning exploration activities in Mesozoic sediment of the margin for hydrocarbon prospects.

Keywords. Flood basalt; Deccan trap; P-wave velocity; Laxmi basin; Northwestern continental margin of India.

\section{Introduction}

The western continental margin of India (WCMI) is formed due to rifting and drifting of India, Madagascar and Seychelles continental blocks, which experienced multiple phases of extensional tectonics in the geological past and evolved in mainly three phases. The first phase of rifting took place between southwestern India and the eastern
Madagascar during the Late Cretaceous under the influence of Marion hotspot volcanism (Norton and Sclater 1979; White and McKenzie 1989; Storey et al. 1995; Torsvik et al. 1998; Raval and Veeraswamy 2003). The short span of rifting between Seychelles-Laxmi ridge and India was the second major tectonic phase, which shaped the western continental margin of India. The Laxmi basin evolved during this phase of rifting but the 
crustal nature underneath the Laxmi basin and the adjacent offshore Indus basin is still being debated from oceanic to stretched continental crust (Bhattacharya et al. 1994; Miles et al. 1998; Talwani and Reif 1998; Krishna et al. 2006; Bhattacharya and Yatheesh 2015; Pandey and Pandey 2015; Ramana et al. 2015). The last phase of rifting commenced between Seychelles and Laxmi ridge-India (Norton and Sclater 1979; Naini and Talwani 1983; Chaubey et al. 2002b) during the Early Paleocene, while the Reunion hotspot activity was in its peak phase. The eastern Somali and conjugate western basin evolved during the phase of seafloor spreading. The crust below the Laxmi ridge was modified during these phases and interpreted to be either continental or oceanic crust (Naini and Talwani 1983; Pandey et al. 1995; Todal and Eldholm 1998; Singh 1999; Radha Krishna et al. 2002; Collier et al. 2008; Misra et al. 2015; Nair et al. 2015). The well developed Tertiary magnetic lineation established by various researchers indicate oceanic nature for the crust beneath the Arabian and eastern Somali basins (Miles and Roest 1993; Chaubey et al. 1998; Dyment 1998; Miles et al. 1998; Chaubey et al. 2002a; Royer et al. 2002).

The Reunion hotspot related volcanism occurred initially on continental shield and later on oceanic region as the Indian plate moved northwards over the hotspot. It created the Deccan Continental Flood Basalt (DCFB) province on the western and central India (Mahadevan 1994) as well as continental flood basalt on the Seychelles microcontinent (Devey and Stephens 1991). Further, it emplaced numerous magmatic intrusions/extrusions within the crust of western continental margin of India as the plate moved over it. The Deccan flood basalt consists of multiple layers of solidified lava flows, which erupted in less than 1 million years (Courtillot et al. 1986; Venkatesan et al. 1993) during the magnetic Chron 29 r ( 65.6-64.8 Ma) through the Cretaceous-Tertiary boundary. Chemical composition of Deccan flood basalt is tholeiitic, highly rich in $\mathrm{Mg}$ and Fe. Richards et al. (1989) estimated total area of flood basalts $>1.5 \times 10^{6} \mathrm{~km}^{2}$, while Todal and Eldholm (1998) estimated it to be $1.8 \times 10^{6} \mathrm{~km}^{2}$. The area covered by Deccan flood basalt on the Indian subcontinent is $5 \times 10^{5} \mathrm{~km}^{2}$ (Mahoney et al. 1989), which is one third of the above estimated area. Therefore, it is believed that nearly an equivalent area of flood basalt adjoining to the DCFB is submerged in the western offshore region of India in the Arabian sea. Offshore extent of flood basalt is poorly reported till now, because of inadequate geophysical and geological data in the offshore region of the WCMI. In order to overcome this problem, $\mathrm{P}$-wave velocity in flood basalt as a proxy, drilled wells results and published seaward dipping reflectors are used to delineate flood basalt on the northwestern continental margin of India. In this study, spatial distribution, depth of occurrence and thickness of the flood basalt on northwestern offshore region of India is reported for the first time.

\section{Structural framework}

The western continental margin of India is a volcanic rifted continental margin. Along with the continental rifting, Reunion hotspot played a major role in shaping up of WCMI and modified the crustal geometry of the region. The northwestern continental margin of India consists of broad shelf as compared to the southwest margin. The present day shelf break along the northwestern continental margin of India occurs at an average water depth of $125 \mathrm{~m}$ (Nair 1975; Rao and Wagle 1997). The width of the continental shelf is more than $300 \mathrm{~km}$ off Mumbai, which makes it one of the largest continental terraces in the world. It decreases towards the north to about $80 \mathrm{~km}$ off Saurashtra and to $\sim 120 \mathrm{~km}$ off Kutch peninsula. Continental shelf of northwestern India is divided into different sedimentary basins namely Kutch, Bombay offshore and Konkan basins (figure 1). A conspicuous southwesterly plunging basement high feature off Saurashtra peninsula is the Saurashtra arch, which is a structural high feature on a regional scale and extends from the shelf to slope. Saurashtra arch separates Kutch basin from Bombay offshore basin (Rao and Talukdar 1980; Mathur and Nair 1993). A similar trending feature, Vengurla arch separates the Bombay offshore basin from the Konkan basin. Bombay offshore basin is the largest among them, which is controlled by several faults and rift system. The Bombay offshore basin is bounded to the north and northwest by Saurashtra peninsula, to the east by Deccan crystalline shield, and to the south by Vengurla arch.

The major rivers, e.g., Indus, Narmada and Tapti drain toward the margin producing a very thick shelf sedimentary column. The shelf in the north is featured typically by longitudinal extensional faults giving rise to a series of narrow horst rraben structures, which are also responsible for widening of the shelf. The style of faulting along the 


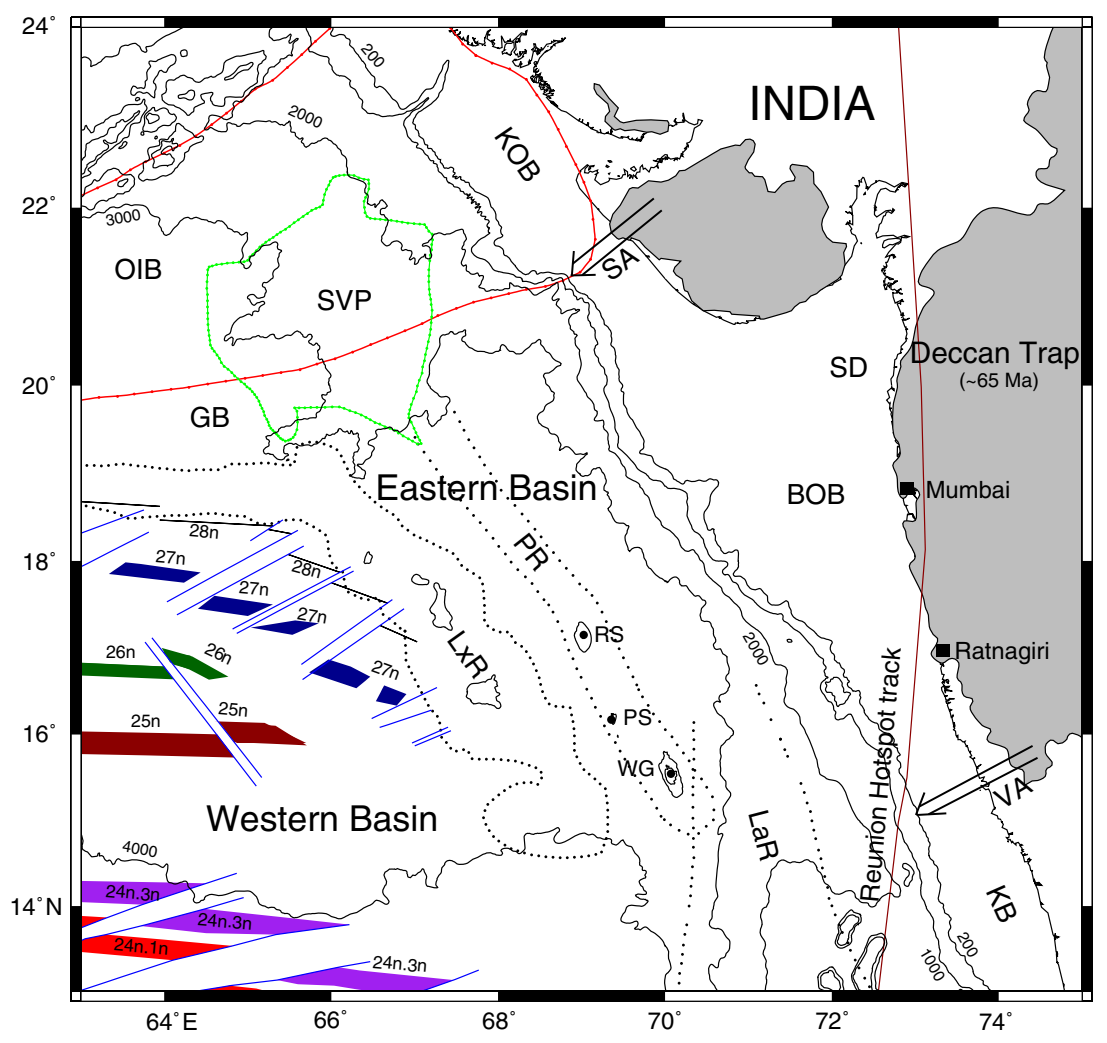

Figure 1. Generalized tectonic map of the western continental margin of India (WCMI) showing major physiographic features and selected bathymetric contours $(\mathrm{m})$. Annotated magnetic lineation (colored strips) are from Chaubey et al. (2002a). Boundaries (dotted lines) of the Laxmi (LxR), Laccadive (LaR) and Panikkar ridges (PR) are from Sreejith et al. (2016), Naini and Talwani (1983) and Krishna et al. (2006), respectively. Offshore Indus basin (OIB) and Saurashtra volcanic platform (SVP) are shown with red and green color polygons, respectively (Carmichael et al. 2009; Corfield et al. 2010). Various sub-basins and basement arches along the WCMI are taken from Biswas (1988). Solid black circles are seamounts. GB: Gop basin, RS: Raman seamount, PS: Panikkar seamount, WG: Wadia guyot, KOB: Kutch offshore basin, SA: Saurashtra arch, SD: Surat depression, BOB: Bombay offshore basin, VA: Vengurla arch, KB: Konkan basin.

west coast is the NW-SE to NNW-SSE Dharwar, NE-SW Aravalli and ENE-WSE to E-W Satpura trends (Biswas 1982, 1987). The Dharwar trend dominates from the Kerala offshore to the Bombay offshore. To the north, in the Gulf of Cambay region, the Satpura trend dominates the structural style, while further north in the KutchSaurashtra region, the Aravalli-Delhi trends are predominant (Biswas 1982). These trends have a bearing on the north to south sequential rifting of Indian subcontinent during the breakup of Gondwanaland (Biswas 1982). Two major conjugate rift systems, Narmada and Cambay, cross each other south of Saurashtra peninsula in the Surat offshore region forming a deep depression known as Surat depression (Biswas 1987). The northwestern continental margin of India and adjacent deep sea region consists of number of tectonic elements; notable amongst them are Laxmi and Laccadive ridges, Laxmi basin, Panikkar ridge, Gop basin, Palitana ridge, etc. The Laxmi and Laccadive ridges are aseismic ridges, which divide the eastern Arabian sea into eastern and western basins (Naini and Talwani 1983). Western basin is typical oceanic in nature while the nature of crust of the eastern basin is still being debated from stretched continental to transitional to oceanic. The Laxmi ridge trends in NW-SE direction and was identified by Naini and Talwani (1983). It is a basement high feature associated with a broad negative freeair gravity anomaly of $\sim 50 \mathrm{mGal}$. Laxmi basin is a relatively gravity high feature in the same trend as of the Laxmi ridge. In the middle of the Laxmi basin, a relative gravity low feature trending NW-SE associated with Panikkar ridge is present and considered to be an extinct spreading center (Bhattacharya et al. 1994; Talwani and Reif 1998). Gop basin, a wide region located between north of $\mathrm{E}-\mathrm{W}$ trending segment of the Laxmi ridge and India-Pakistan continental shelf, lies between latitudes $19^{\circ}$ and $20^{\circ} \mathrm{N}$ (Malod et al. 1997; Yatheesh et al. 2009). The Laccadive ridge is the northern 


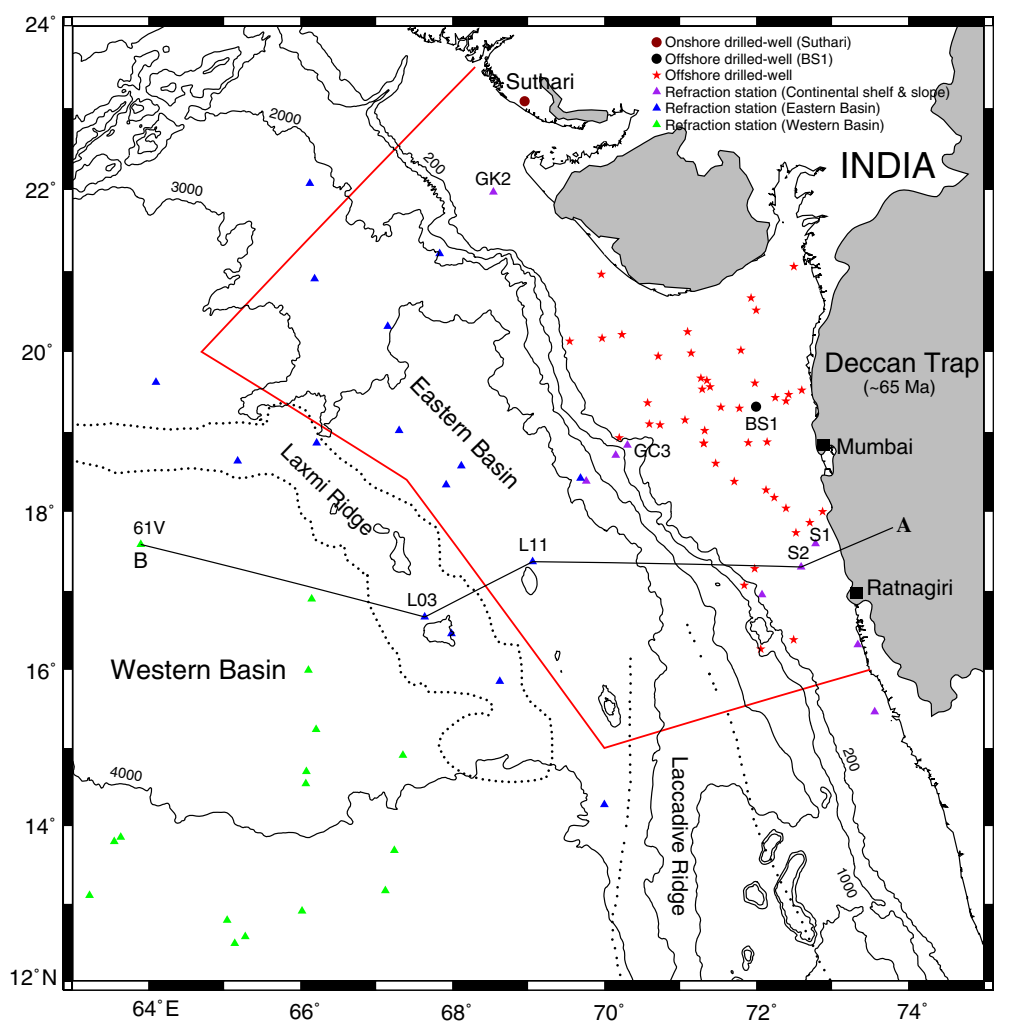

Figure 2. Map showing location of geophysical data in the study area bounded by red polygon. Dark red solid circle on onshore represents drilled-well Suthari (Pandey et al. 2011). Black solid circle: offshore drilled-well BS-1, red solid stars: drilled-wells in western offshore, purple solid triangles: refraction stations on the continental shelf and slope region (Rao 1967, 1970), blue solid triangles: refraction stations in the eastern basin (Naini and Talwani 1983), green solid triangles: refraction stations in the western basin (Naini and Talwani 1983). Selected bathymetric contours (m) are shown as continuous black line. An arbitrary line $\mathrm{AB}$ is chosen for correlation of $\mathrm{P}$-wave velocity of crustal layers from onshore to offshore.

segment of Chagos-Laccadive ridge corresponds to the general $\mathrm{N}-\mathrm{S}$ trend and is associated with a negative gravity anomaly. However, relatively positive anomaly can be observed over some crestal region of this ridge. Study area (figure 2) includes northwestern continental margin of India and adjoining deep sea region, and is bounded by northwest coast of India in the northeast, Laxmi ridges in the southwest, Laccadive ridge in the south and Murray ridge in the northwest.

\section{Data}

The northwestern offshore region of India was investigated to provide spatial distribution, depth of occurrence and thickness of flood basalt using two sets of data: onshore as well as offshore geophysical data. The details of data types used here are described briefly in the following sections.

\subsection{Onshore data}

Onshore data comprises P-wave velocities (Kaila et al. 1981a, b, 1987, 1989a,b, 1990; Kaila and
Krishna 1992; Kumar et al. 2000; Reddy 2005; Murty et al. 2010) in Deccan flood basalt, which are derived from Deep Seismic Sounding (DSS) surveys carried out by National Geophysical Research Institute, Hyderabad, India. P-wave velocity derived from earthquake data (Krishna 2004) and from dispersion of short-period Love wave data (Tandon 1973), is utilized in this study. In addition, sonic log and litholog data of a drilled-well (Suthari) (Pandey et al. 2009, 2011) located in Kutch, Gujarat $\left(23.12^{\circ} \mathrm{N}, 68.92^{\circ} \mathrm{E}\right)$ are also used in this study.

\subsection{Offshore data}

Offshore data consists of published results on litholog of wells drilled by Oil and Natural Gas Corporation (ONGC) and P-wave velocity from refraction survey. Drilled well data where flood basalt was encountered, has been compiled (figure 2) from various publications (Sahay 1978; Roychoudhury and Deshpande 1982; Parida and Mishra 1992; Mathur and Nair 1993; Senapati et al. 1993; 


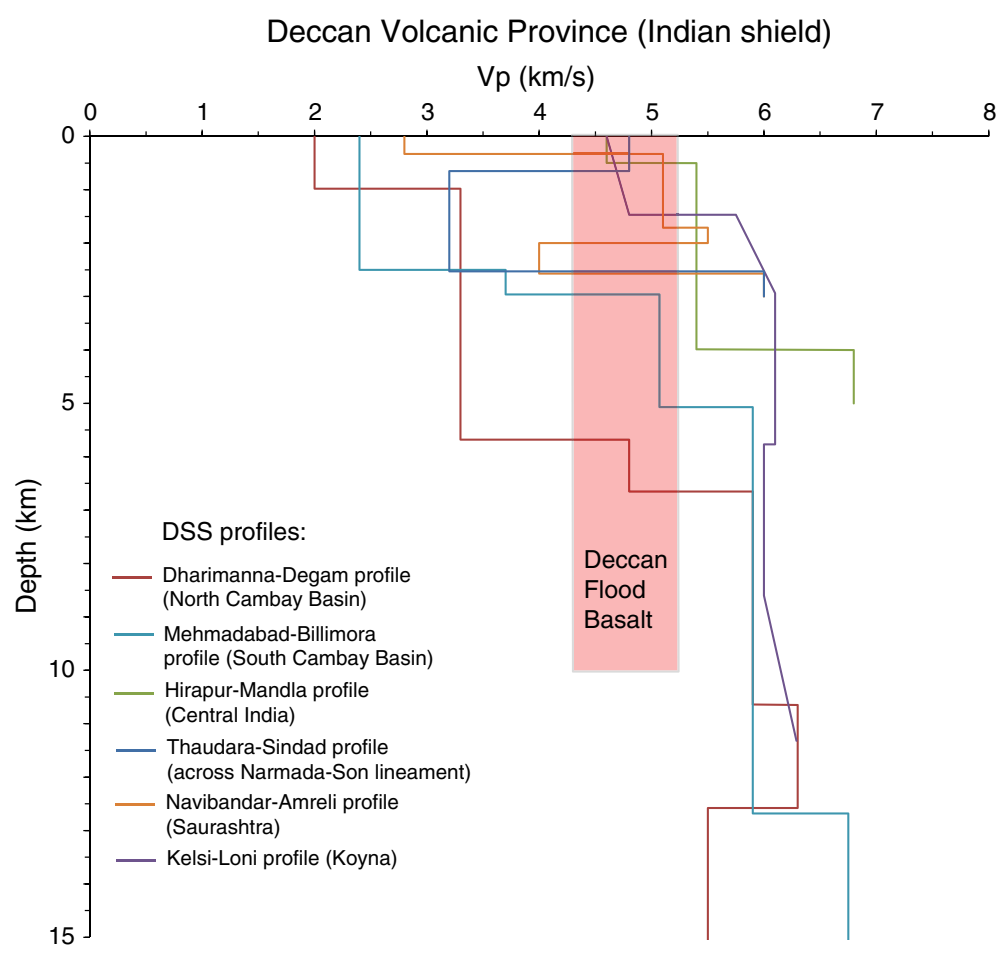

Figure 3. Velocity-depth plot of Deep Seismic Sounding (DSS) profiles in Deccan volcanic province. P-wave velocity in Deccan flood basalt (shaded portion) varies from 4.3 to $5.2 \mathrm{~km} / \mathrm{s}$.

Pandey and Dave 1998) to determine depth of occurrence of flood basalt. In addition, those drilled wells which did not encounter flood basalt are also compiled. Refraction data are compiled (Rao 1967, 1970; Naini and Talwani 1983), which show velocity structure of the western basin, eastern basin and western continental shelf of India. Total 44 offshore drilled-wells, 9 refraction stations on shelf and slope, 11 refraction stations in the eastern basin, 5 refraction stations on the Laxmi ridge and 16 refraction stations on the western basin are used in the present study.

\section{Delineation of flood basalt}

To map offshore extent of flood basalt, a typical $\mathrm{P}$-wave velocity in flood basalt is used as a proxy. In addition, drilled well results, and published seaward dipping reflectors are used to delineate flood basalt extent and its thickness on the northwestern continental margin of India.

\subsection{Representative P-wave velocity in flood basalt}

Deep Seismic Sounding (DSS) data has provided valuable information about the basement configuration and velocity distribution up to the Moho in Deccan volcanic province (DVP). DSS profiles along Dharimanna-Degam (Kaila et al. 1990), Mehmadabad-Billimora (Kaila et al. 1981b), Hirapur-Mandla (Kaila et al. 1987, 1989b), Thaudara-Sindad(Kaila et al. 1989a), NavibandarAmreli (Kaila and Krishna 1992), and Kelsi-Loni (Kaila et al. 1981a) have been considered to determine P-wave velocity in the Deccan flood basalt. Velocity-depth plots of different DSS profiles (figure 3) show that the $\mathrm{P}$-wave velocity in Deccan flood basalt ranges from 4.3 to $5.2 \mathrm{~km} / \mathrm{s}$. Similarly, P-wave velocity in the Deccan flood basalt is also reported from dispersion of shortperiod Love wave and earthquake data, which display a range of $4.7-5.2 \mathrm{~km} / \mathrm{s}$ (Tandon 1973) and $4.8-4.9 \mathrm{~km} / \mathrm{s}$ (Krishna 2004), respectively. The Pwave velocities in Deccan flood basalt derived from available literature are presented in table 1 , which show that it varies from 4.3 to $5.2 \mathrm{~km} / \mathrm{s}$.

An onshore drilled-well (Suthari), which is drilled up to $\sim 2750 \mathrm{~m}$ but did not reach up to Precambrian basement (Pandey et al. 2011), is utilized to correlate with sonic $\log$ and refraction derived P-wave velocity. Litholog data of Suthari revealed (i) about $600 \mathrm{~m}$ thick sedimentary strata of Quaternary-Tertiary period, (ii) 600 m thick Deccan basalt layer, (iii) 1000 m thick sandstoneclaystone of early Late Cretaceous period, and 
Table 1. P-wave velocity in Deccan flood basalt derived from Deep Seismic Sounding survey.

\begin{tabular}{|c|c|c|c|}
\hline No. & Name of the profile & $\begin{array}{l}\text { P-wave } \\
\text { velocity }(\mathrm{km} / \mathrm{s}) \\
\text { in flood basalt }\end{array}$ & Reference \\
\hline 1 & Koyna I (Guhagar-Chorochi) profile & $4.7-4.9$ & (Kaila and Krishna 1992) \\
\hline 2 & Koyna II (Kelsi-Loni) profile & $4.8-5.0$ & $\begin{array}{l}\text { (Kaila et al. 1981b; Kaila and } \\
\text { Krishna 1992) }\end{array}$ \\
\hline 3 & Saurashtra Peninsula (Navibandar-Amreli) Profile & $4.9-5.15$ & (Kaila and Krishna 1992) \\
\hline 4 & Mehmadabad-Billimora in southern Cambay Basin & $4.8-5.2$ & $\begin{array}{l}\text { (Kaila et al. 1981a; Kaila and } \\
\text { Krishna 1992) }\end{array}$ \\
\hline 5 & Thuadara-Sindad profile & $4.7-5.0$ & $\begin{array}{l}\text { (Kaila et al. 1989a; Kaila and } \\
\text { Krishna 1992) }\end{array}$ \\
\hline 6 & Ujjain-Mahan profile & $4.7-5.1$ & (Kaila and Krishna 1992) \\
\hline 7 & Khajuria Kalan-Pulgaon profile & $4.7-5.1$ & (Kaila and Krishna 1992) \\
\hline 8 & Hirapur-Mandla profile & $4.5-4.8$ & $\begin{array}{l}\text { (Kaila et al. 1987, 1989b; } \\
\text { Kaila and Krishna 1992) }\end{array}$ \\
\hline \multirow[t]{3}{*}{9} & Narmada region & & \\
\hline & Profile II (Khajuriakalan-Pulgaon) & $4.4-4.6$ & (Kumar et al. 2000) \\
\hline & Profile III (Ujjain-Mahan) & $4.3-4.5$ & \\
\hline \multirow[t]{3}{*}{10} & Narmada-Tapti region & & \\
\hline & Narayanpur-Nandurbar & $4.5-4.7$ & (Murty et al. 2010) \\
\hline & Kothari-Sakri & $4.5-5.2$ & \\
\hline 11 & Jodin-Ansodor profile & 4.9 and 5.1 & (Reddy 2005) \\
\hline 12 & Tikor-Kolithad profile & 5.1 & (Reddy 2005) \\
\hline 13 & Kurungo-Latipur profile & 4.8 & (Reddy 2005) \\
\hline 14 & Sardar-Mangrol profile & 5.1 & (Reddy 2005) \\
\hline $15^{*}$ & Analysis of Jabalpur earthquake & $4.8-4.9$ & (Krishna 2004) \\
\hline $16^{*}$ & Bombay-Koyna & $4.7-5.2$ & (Tandon 1973) \\
\hline
\end{tabular}

*P-wave velocity $4.8-4.9 \mathrm{~km} / \mathrm{s}$ and $4.7-5.2 \mathrm{~km} / \mathrm{s}$ mentioned at Sl. no. 15 and 16 respectively are obtained from analysis of earthquake data.

(iv) Middle to Late Jurassic alternate bands of limestone and sandstone (figure 4a). Sedimentary layers of early Late Cretaceous and middle Late Jurassic period represent Mesozoic sediments, which can have potential for hydrocarbon accumulation. Corresponding sonic log data of the drilled-well Suthari (Pandey et al. 2009) revealed $\mathrm{P}$-wave velocity of $1.9-2.2 \mathrm{~km} / \mathrm{s}$ in the Tertiary sediment, $4.5-4.6 \mathrm{~km} / \mathrm{s}$ in the Deccan flood basalt, followed by low velocity $\left(V_{\mathrm{p}}=3.2 \mathrm{~km} / \mathrm{s}\right)$ Mesozoic sedimentary strata. In order to investigate existence of offshore flood basalt, an offshore refraction station (GK2) is chosen, which is located $\sim 130 \mathrm{~km}$ southwest of the onshore drilled well (Suthari). The $\mathrm{P}$-wave velocity obtained from an offshore refraction station (GK2) is correlated (figure 4a) with the sonic and litholog data of the onshore drilled well (Suthari). The velocity-depth plot at refraction station GK2 revealed that P-wave velocity varies from 2.08 to $3.2 \mathrm{~km} / \mathrm{s}$ in $\sim 1400 \mathrm{~m}$ thick sedimentary strata, which is underlain by a $\sim 2000$ m thick crustal layer of velocity $4.3 \mathrm{~km} / \mathrm{s}$. The crust underlying the above layer is represented by the velocities 5.27 and $6.24 \mathrm{~km} / \mathrm{s}$, which are interpreted to be upper and lower continental crust, respectively. Thickness of upper crust is $\sim 2000 \mathrm{~m}$ but no information is available on the thickness of lower crust at this refraction station. Litholog, sonic log and offshore refraction derived $\mathrm{P}$-wave velocity clearly indicate that crustal layer with $V_{\mathrm{p}}=4.3 \mathrm{~km} / \mathrm{s}$ underlying the sedimentary strata $\left(V_{\mathrm{p}}=2.08-3.2 \mathrm{~km} / \mathrm{s}\right)$ closely matches with the velocity $(4.5-4.6 \mathrm{~km} / \mathrm{s})$ in the Deccan flood basalt observed in sonic log.

Further, litholog data of an offshore drilled-well BS-1 (Sahay 1978), located in the Bombay offshore basin (figure 2), confirms presence of flood basalt below $\sim 2145 \mathrm{~m}$ thick Quaternary-Tertiary sedimentary strata. The well BS-1 is drilled up to $\sim 2150$ and $\sim 5 \mathrm{~m}$ thick flood basalt is encountered up to this depth. P-wave velocity obtained from an offshore refraction station $\mathrm{S} 1$, located $\sim 180 \mathrm{~km}$ southeast of the offshore drilled-well BS-1, is correlated with the litholog data of BS-1 


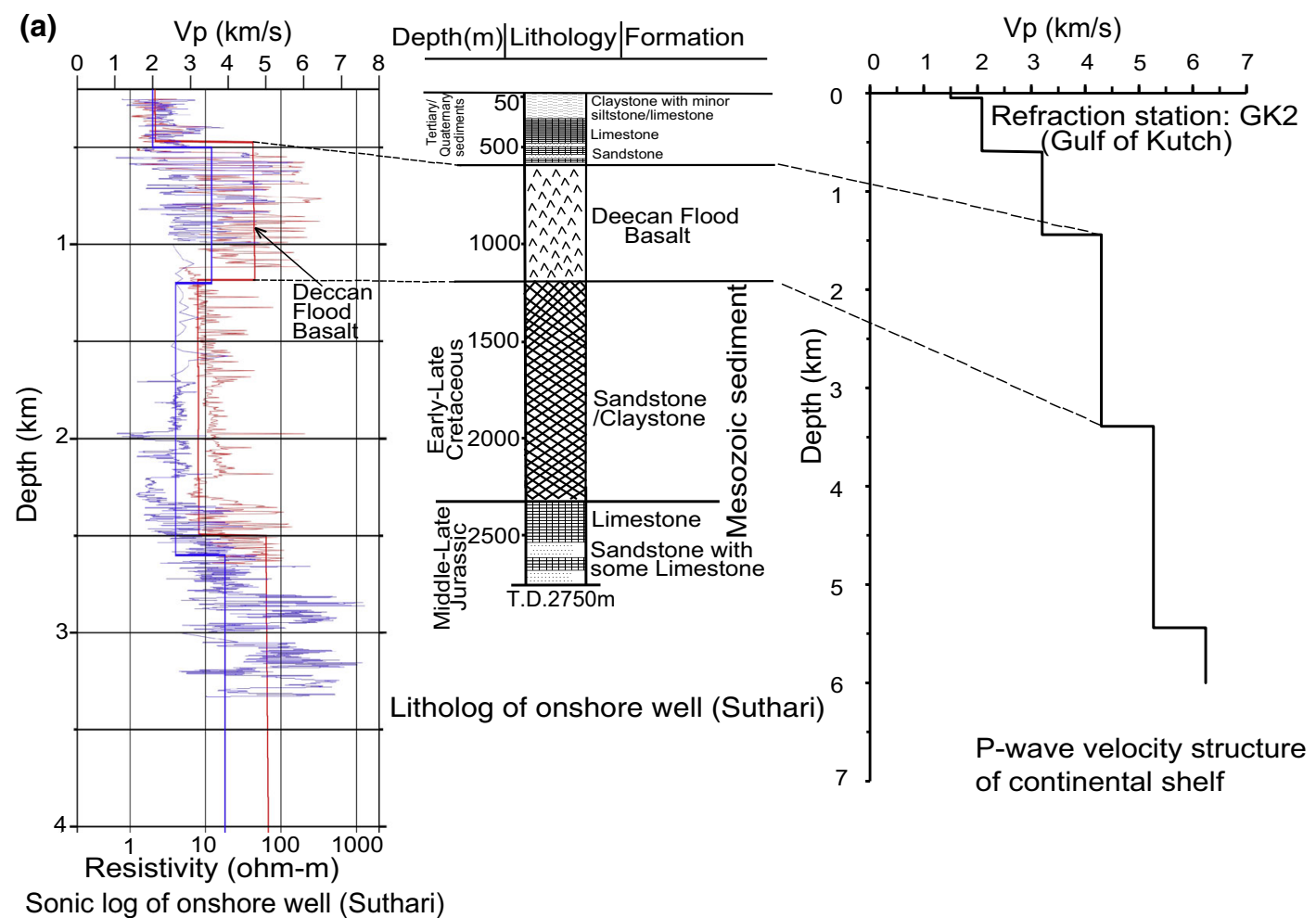

(b)

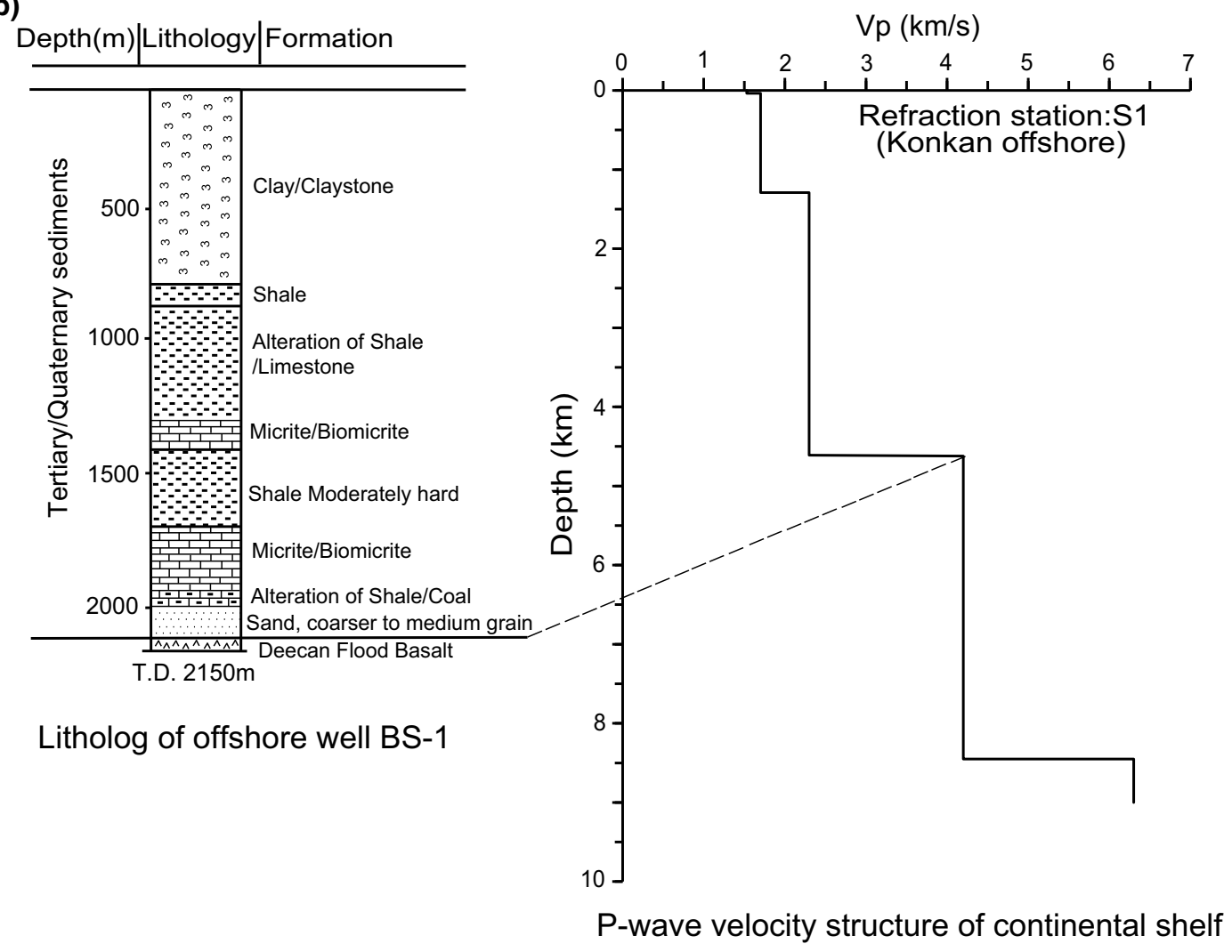

Figure 4. (a) Correlation of sonic log and litholog of onshore well (Suthari) (modified from Pandey et al. 2009, 2011) shows that P-wave velocity ranges from 4.5 to $4.6 \mathrm{~km} / \mathrm{s}$ in Deccan flood basalt. Their further correlation with refraction derived P-wave velocity at refraction station GK2 (Gulf of Kutch) suggest that velocity of $4.3 \mathrm{~km} / \mathrm{s}$ represents flood basalt. (b) Correlation of litholog data of offshore well (BS-1) (modified from Sahay 1978) and refraction derived P-wave velocity at refraction station S1 (Konkan shelf) suggest that P-wave velocity of $4.2 \mathrm{~km} / \mathrm{s}$ represents flood basalt. 


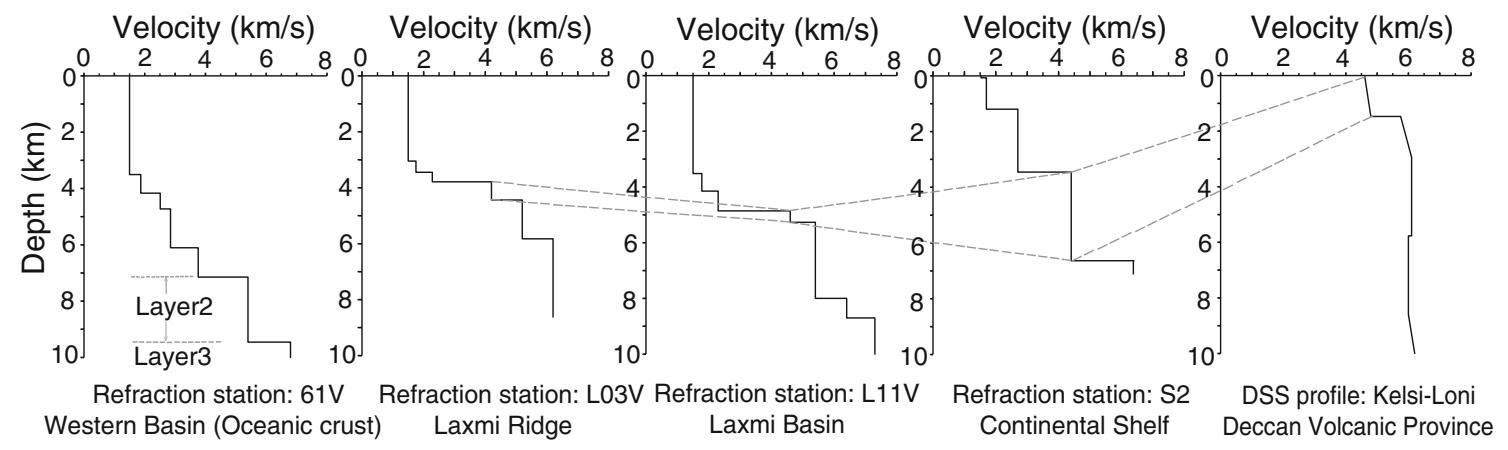

Figure 5. Velocity-depth plots along an arbitrary line AB (shown in figure 2), starting from point A at Koyna (onshore region) and passing through refraction stations S2 (continental shelf), L11V34 (Laxmi basin), L03V34 (Laxmi ridge) and 61 V34 (western basin). Velocity correlation from onshore region to the Laxmi ridge along line AB reveals a consistent layer with P-wave velocity ranging from 4.2 to $4.6 \mathrm{~km} / \mathrm{s}$, which represents flood basalt. Such velocity range is absent in the western basin.

(figure $4 \mathrm{~b}$ ). P-wave velocity at this station varies from 1.7 to $2.3 \mathrm{~km} / \mathrm{s}$ in $\sim 4500 \mathrm{~m}$ thick crustal layers, followed by a $\sim 3900 \mathrm{~m}$ thick layer of velocity $4.2 \mathrm{~km} / \mathrm{s}$. Correlation of the litholog and the refraction derived $\mathrm{P}$-wave velocity suggests that crustal layer with $V_{\mathrm{p}}=1.7-2.3 \mathrm{~km} / \mathrm{s}$ represent sedimentary layer and crustal layer underlying it with $V_{\mathrm{p}}=4.2 \mathrm{~km} / \mathrm{s}$ represent flood basalt. Location of onshore drilled-well (Suthari), offshore drilled-well BS-1 and refraction stations GK2 and S1 are shown in figure 2.

In view of the above results, we suggest that representative $\mathrm{P}$-wave velocity in flood basalt on the onshore as well as offshore region lies in the range of $4.2-5.2 \mathrm{~km} / \mathrm{s}$, which is used in this study as a proxy to map flood basalt in the study area.

\subsection{Extent and thickness of flood basalt}

The ONGC Ltd., India drilled several wells on the northwestern continental shelf of India and encountered flood basalt in several drilled wells. Even though, some of the drilled-wells did not encounter flood basalt in its drilled section, chronostratigraphic section using litholog data indicated occurrence of flood basalt on the shelf except at some isolated high features in Bombay High and HeeraBassein block (Mathur and Nair 1993). Beyond the continental shelf, occurrence of flood basalt is investigated using $\mathrm{P}$-wave velocity as a proxy. P-wave velocity structures along arbitrary line $\mathrm{AB}$ (figures 2 and 5) is chosen for the comparison of crustal velocities. Line $\mathrm{AB}$ spans from onshore to offshore passing through point $\mathrm{A}$ at Koyna (onshore region), and refraction stations S2 (continental shelf), L11V34 (Laxmi basin), L03V34 (Laxmi ridge) and 61V34 (western basin).
Velocity-depth plot of Kelsi-Loni profile in Koyna region shows that $\mathrm{P}$-wave velocity varies from $4.6-4.8 \mathrm{~km} / \mathrm{s}$ in Deccan flood basalt and $5.75-6.29 \mathrm{~km} / \mathrm{s}$ in the upper continental crust. Refraction station $\mathrm{S} 2$ on the continental shelf shows $\sim 3400 \mathrm{~m}$ thick sedimentary strata with $V_{\mathrm{p}}$ ranging between 1.7 and $2.7 \mathrm{~km} / \mathrm{s}$, followed by $\sim 3200 \mathrm{~m}$ thick layer of $V_{\mathrm{p}}=4.4 \mathrm{~km} / \mathrm{s}$. In the Laxmi basin, velocity structure at refraction station L11V34 reveals $\sim 1300 \mathrm{~m}$ thick sedimentary strata of velocity ranging between 1.78 and $2.3 \mathrm{~km} / \mathrm{s}$, followed by $\sim 400 \mathrm{~m}$ thin layer of velocity $4.6 \mathrm{~km} / \mathrm{s}$ overlying a layer of velocity $5.4 \mathrm{~km} / \mathrm{s}$. On the Laxmi ridge, refraction station L03V34 reveals $\sim 740 \mathrm{~m}$ thin sedimentary strata with $V_{\mathrm{p}}$ ranging from 1.75 to $2.28 \mathrm{~km} / \mathrm{s}$, underlain by a thin layer $(\sim 650 \mathrm{~m})$ with velocity $4.2 \mathrm{~km} / \mathrm{s}$. Underlying this layer, two layers with velocity 5.2 and $6.2 \mathrm{~km} / \mathrm{s}$ are present. Refraction station 61V34 located in the western basin depicts $\sim 3600 \mathrm{~m}$ thick sediment with velocity $1.87-3.76 \mathrm{~km} / \mathrm{s}$, underlain by layers with velocity of 5.4 and $6.8 \mathrm{~km} / \mathrm{s}$, which represents layers 2 and 3 of typical oceanic crust at depth of 7.145 and $9.455 \mathrm{~km}$, respectively (figure 5). This refraction station does not show any layer of velocity ranging between 4.2 and $5.2 \mathrm{~km} / \mathrm{s}$.

The velocity structure of the continental shelf, Laxmi basin and Laxmi ridge along the line $\mathrm{AB}$ reveal a consistent layer $\left(V_{\mathrm{p}}=4.2-4.6 \mathrm{~km} / \mathrm{s}\right)$ with variable depth and thickness below Quaternary/Tertiary sediments. All the refraction stations located in the eastern basin and on the Laxmi ridge reveal a consistent layer, located immediately below the sedimentary strata, of P-wave velocity ranging from $4.1-4.9 \mathrm{~km} / \mathrm{s}$. Therefore, considering $V_{\mathrm{p}}$ in Deccan flood basalt $(4.2-5.2 \mathrm{~km} / \mathrm{s})$ as proxy and the fact that it lie below the sedimentary 


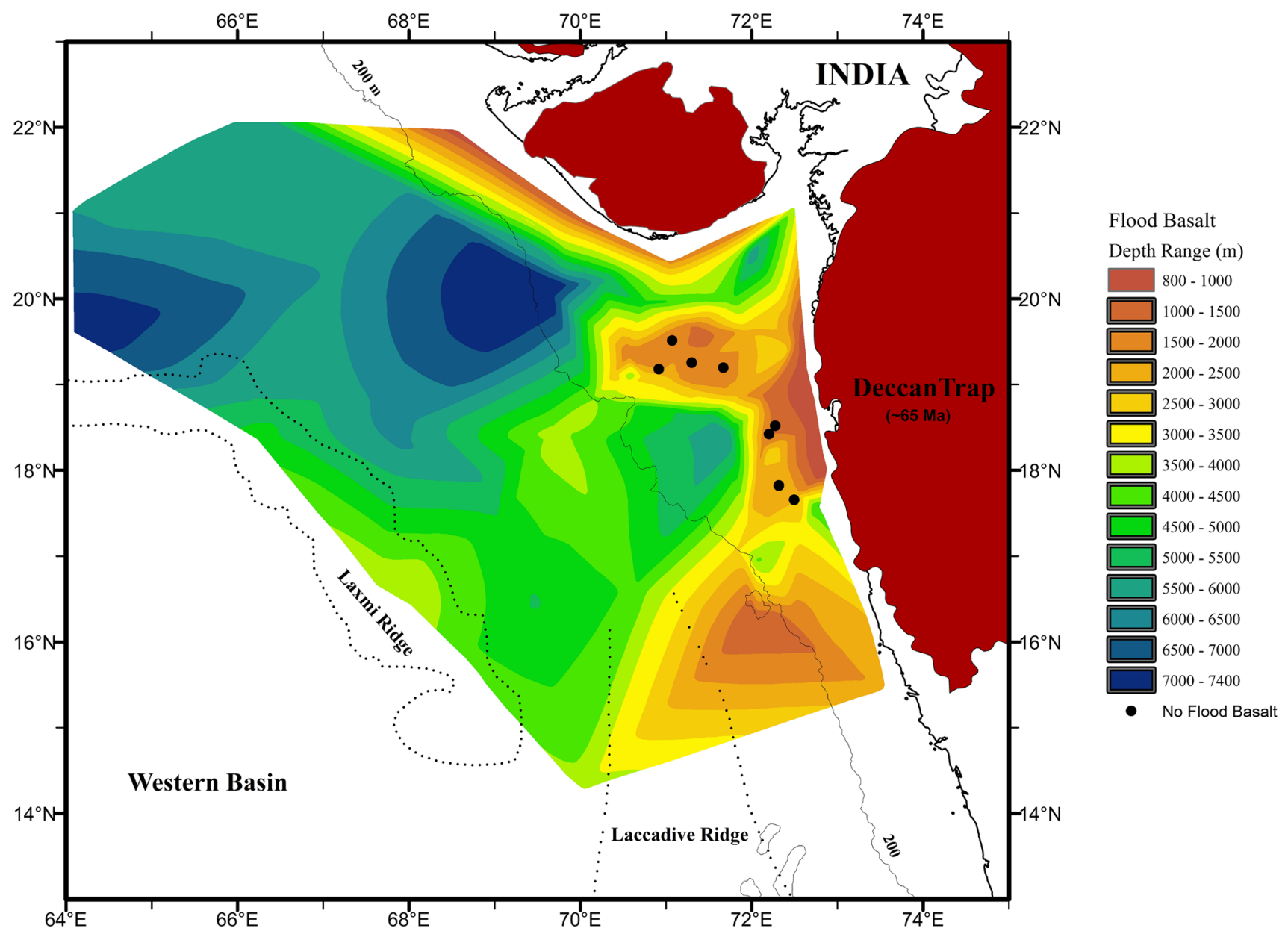

Figure 6. Map depicting extent and depth of occurrence of flood basalt. Circles represent those drilled-wells, which reached up to granitic basement without encountering flood basalt.

strata, the layer with velocity range $4.1-4.9 \mathrm{~km} / \mathrm{s}$ is interpreted as flood basalt. It may be mentioned here that the adjacent western basin is oceanic in nature, and therefore does not show any layer of such velocity representing flood basalt (figure 5).

High resolution ion-GXT seismic lines indicated presence of seaward dipping reflectors (SDRs) below sedimentary strata on the NWCMI (Misra et al. 2015). Further, study carried out by Planke (1994) using wire line log at Ocean Drilling Program Site 642 located on Voring volcanic margin off Norway revealed tholeiitic lava flow (flood basalt) representing SDRs. Litholog of drilled site in IODP Leg 355 U1457 in the Laxmi basin also shows the presence of basaltic lava flow underlying the Paleocene sediment at depth of $\sim 1100 \mathrm{~m}$ below seafloor (Pandey et al. 2016). These results support our interpretation of occurrence of flood basalt immediately below the sedimentary strata on the NWCMI.

On the basis of drilled-well data, P-wave velocity in flood basalt, and published seismic section, a database of occurrence of flood basalt is prepared.
Based on the database, a map showing extent as well as depth of occurrence is prepared and presented in figure 6 . The results suggest that the flood basalt is present on the entire northwestern continental margin of India and extends up to the Laxmi ridge, except at some isolated high. Correlation of those drilled-wells, which penetrated granitic basement without encountering flood basalt with chronostratigraphic section (Mathur and Nair 1993) on the northwestern continental shelf of India, revealed its location above isolated high features. It may also be possible that some of isolated high features located in the eastern basin and on the Laxmi ridge are devoid of flood basalt.

The thickness of flood basalt is estimated using $\mathrm{P}$-wave velocity structure derived from seismic refraction data is presented in figure 7 . Though a few refraction stations on the shelf and slope region do show thickness of flood basalt but they are too sparse to prepare flood basalt thickness contour map. 


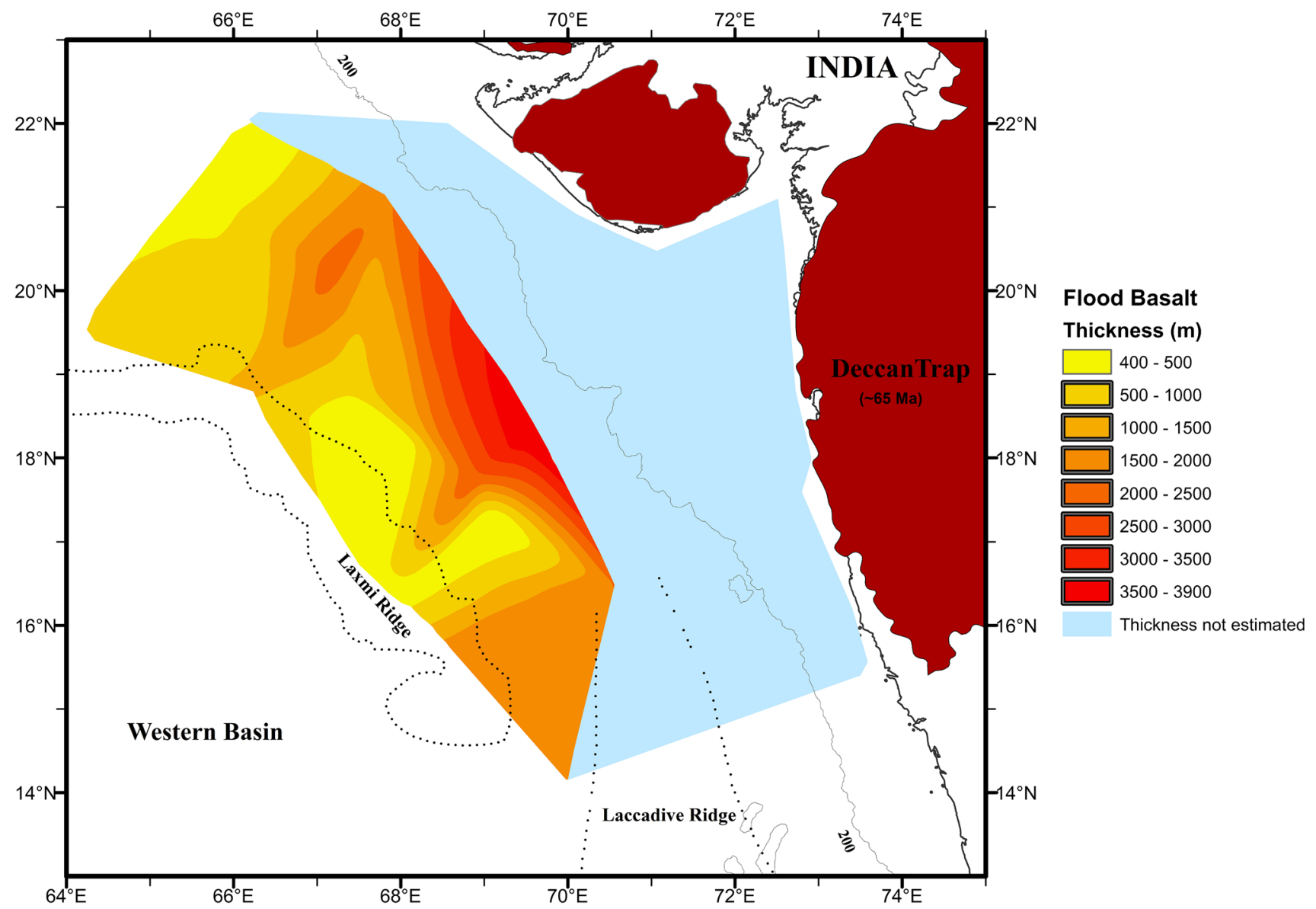

Figure 7. Map showing thickness of flood basalt determined from the present study. Light blue color shaded area represents presence of flood basalt but its thickness could not be determined. Though a few refraction stations, in this area, do show thickness of flood basalt but they are too sparse to prepare flood basalt thickness contour map. Boundaries of the Laxmi and Laccadive ridges are shown with dotted curve.

\section{Results and discussion}

The results of the present study show that depth of occurrence of flood basalt ranges from 800 to 7400 $\mathrm{m}$ in the study area. Deeper occurrences of flood basalts below the Tertiary sediment are found in the Gop basin at a depth of $\sim 7400$ and $\sim 7200 \mathrm{~m}$ at the foot of slope of Saurashtra continental slope. Depth of flood basalt decreases from $7400 \mathrm{~m}$ in the Gop basin to $6000 \mathrm{~m}$ further northward. Occurrence of flood basalt near the Gop basin is also reported in recent publications (Carmichael et al. 2009; Corfield et al. 2010; Calvès et al. 2011). Further, Carmichael et al. (2009) inferred occurrence of flood basalt at a depth of about $6500 \mathrm{~m}$, north of the deepest occurrence of flood basalt (in the Gop basin) interpreted in the present study.

The deeper occurrence of flood basalt may be due to post-Trappean thick sedimentation and excess subsidence in the region. Further, a large variation in the depth of occurrence of flood basalt in the study area suggest that the volcanic emplacement was controlled by existing tectonic features in the region.

The occurrence of flood basalt is also interpreted on the Laxmi ridge, where it is observed at an average depth of $\sim 4000 \mathrm{~m}$. Seaward dipping reflector was observed west of Laxmi ridge (Krishna et al. 2006; Collier et al. 2008; Corfield et al. 2010), which support the extent of flood basalt up to the Laxmi ridge. SDRs with a wide range of $\mathrm{P}$-wave velocity 3.0 to $5.5 \mathrm{~km} / \mathrm{s}$ were reported on the volcanic rifted margins by Planke et al. (2000). However, P-wave velocity range $1.5-3.5 \mathrm{~km} / \mathrm{s}$ correspond to sediments in the study area (Rao 1967, 1970; Naini and Talwani 1983). Therefore, $V_{\mathrm{p}}$ less than $3.5 \mathrm{~km} / \mathrm{s}$ do not represent SDR (flood basalt) in the study area.

The depth of flood basalt increases eastward from the Laxmi ridge to the Laxmi basin. In the Laxmi basin, it varies from 4000 to $6000 \mathrm{~m}$. Krishna et al. (2006) suggested that intrusive structures 
in the form of dykes and accretion of magmatic material in the form of sills emplaced in the Laxmi basin possibly generated by the Reunion hotspot at the time of Deccan volcanism. Pandey and Pandey (2015) suggested that the Laxmi basin is heavily intruded by sills and basaltic volcanic, which were emplaced due to melting of sub-continental mantle (SCM). They also proposed that Panikkar ridge is a basaltic volcanic body derived from melting of lower part of the SCM. Results of the drilling at site U1457 in the Laxmi basin during International Ocean Discovery Program (Expedition 355) recovered $8.72 \mathrm{~m}$ of basalt, as well as associated volcaniclastic sediment above it (Pandey et al. 2016). Shore-based geochemical analysis carried out after the end of the expedition shows that the basalt is Mg-rich, low-K sub-alkalic tholeiites. All these observations support presence of flood basalt in the Laxmi basin and on the Laxmi ridge.

The continental shelf north of Ratnagiri, India is associated with horst-graben structures. The shelf region hosts several sedimentary basins (Kutch offshore basin, Bombay offshore basin and Konkan basin), which are separated by WSW-ENE basement arches (Saurashtra and Vengurla arch). The depth of flood basalt in Bombay offshore basin is quite random, where it varies from $\sim 1000$ to 4000 m. Flood basalt in Bombay High region occurs at a depth of $\sim 2000 \mathrm{~m}$, except at some isolated high features where flood basalt is not present. Bombay High is an uplifted basement structure and is bounded by faults on either side. It has a gentle dip of $2^{\circ}$ to $3^{\circ}$ on the western side and steep dip of $8^{\circ}$ to $10^{\circ}$ on the eastern side (Murti et al. 1981). Therefore, depth of flood basalt increases in either sides of the Bombay High except in the eastern side, where it decreases and reaches up to $<1000 \mathrm{~m}$. Bombay offshore basin is an intracratonic basin which came into existence during upper cretaceous due to faulting in the Deccan trap basement. In the Bombay offshore basin, some of the drilledwells penetrated into Tertiary strata and entered the Archean basement without encountering the flood basalt (Rao and Srivastava 1981; Roychoudhury and Deshpande 1982; Sahay 1984).

The depth of flood basalt increases up to $\sim 4000$ $m$ northeast of the Bombay High, along Surat depression where thick sediment is deposited. Since, the southern part of the Cambay basin and Surat depression are the depocentres that have received sediments brought down by Narmada-Tapti river system (Nair et al. 1992), therefore observed depth of occurrence of flood basalt of $\sim 5500 \mathrm{~m}$ in the region is interpreted due to post-Trappean subsidence of the crust.

Maximum and minimum thickness of flood basalt is interpreted as $\sim 3900 \mathrm{~m}$ in the Laxmi basin and $\sim 400 \mathrm{~m}$ on the Laxmi ridge, respectively (figure 7 ). Thickness decreases from east to west over the Laxmi ridge, where flood basalt layer terminates at the western side of the Laxmi ridge. All along the Laxmi basin flood basalt thickness vary from 400 to $2000 \mathrm{~m}$ but northern and southern part of the Laxmi basin show relatively high thickness. Flood basalt thickness ranges from 500 to $1000 \mathrm{~m}$ in the Gop basin and decreases further northward. Misra et al. (2015) has shown that the thickness of inner SDRs are less than $5 \mathrm{~km}$. Further, geophysical study carried out by Corfield et al. (2010) on western Indian and Pakistan continental margins revealed major variation in overall thickness and style of volcanism across the margin both in dip and strike direction, which they believed to be related to variability in the influence of the Deccan plume, in addition to localization along structural features inherited from older tectonic events.

It is worth mentioning here, that flood basalt thickness map in figure 7 has been prepared using seismic refraction data which contains crustal information till Moho. Such refraction data are available on the Laxmi ridge and eastern basin only. Though there are few refraction stations on the continental shelf and slope region, which provide velocity information and thickness of flood basalt, they are widely spaced and not sufficient to prepare thickness map. Therefore, the thickness of flood basalt in the shelf and slope region is not presented.

The study of Deccan flood basalt is very important due to presence of Mesozoic sediment hidden below it. Worldwide Mesozoic sediment contribute around $54 \%$ of oil and $44 \%$ of gas reserves. Geophysical surveys carried out in the Indian Mesozoic basins have indicated presence of significant sediment thickness. These basins are mostly overlain by Deccan flood basalt of Late Cretaceous and are least explored. Mesozoic sediments are plausible for hydrocarbon accumulation having suitable trapping mechanism due to overlying thick layer of flood basalt. Further, it is also considered that the Deccan flood basalt volcanism, soon after the Mesozoic sedimentation, has provided sufficient thermal gradient and might have acted as a catalyst in hydrocarbon generation. Further, it is believed that the volcanism must have 
had a profound influence on the crustal evolution including the present-day configuration of the continental margin concealing the pre-existing geology and crustal structure. The study provides a firsthand information about flood basalt extent and its thickness on the northwestern continental margin of India, which can help to delineate hydrocarbon potential in Mesozoic sediment hidden below the flood basalt layer. The results of the present study warrant integrated gravity and magnetic modelling under constraints of the results of the present study in order to provide refined maps showing extent, depth of occurrence and thickness of flood basalt on the northwestern continental margin of India.

\section{Conclusions}

The study presented in this article provides insights on the extent, depth of occurrence and thickness of flood basalt on the northwestern continental margin of India and adjoining deep sea region. Analysis of $\mathrm{P}$-wave velocity in the study area and adjoining onshore region reveals that velocity of $4.1-5.2 \mathrm{~km} / \mathrm{s}$ represent flood basalt, which is spread all over northwestern continental margin of India. It extends up to the Laxmi and Laccadive ridges, except at some isolated high features, and is absent in the western basin, west of the ridges. The flood basalt occurs between 800 and $7400 \mathrm{~m}$ below sea level and its maximum thickness $(\sim 3900 \mathrm{~m})$ is observed at foot of the continental slope near eastern part of the Laxmi basin. A large variation in the depth of occurrence and thickness of flood basalt in the study area suggest that the volcanic emplacement was controlled by existing tectonic features in the region. The results of present study have major implications due to the presence of Mesozoic sediments hidden below the flood basalt and may be useful to understand hydrocarbon preservation condition for conceptual evaluation of hydrocarbon potential of the region.

\section{Acknowledgements}

The authors are thankful to Prof Sunil Kumar Singh, Director, CSIR-National Institute of Oceanography, Goa for support, encouragement and permission to publish this work. We are also grateful for the critical review and constructive comments by two anonymous reviewers, which helped to improve the manuscript. PK, Senior Research Fellow, thanks the Council of Scientific and Industrial Research, New Delhi for financial assistance in the form of Senior Research Fellowship. This is CSIR-NIO's contribution no. 6256.

\section{References}

Bhattacharya G C, Chaubey A K, Murty G P S, Srinivas K, Sarma K V L N S, Subrahmanyam V and Krishna K S 1994 Evidence for seafloor spreading in the Laxmi basin, northeastern Arabian sea; Earth Planet. Sci. Lett. 125 211-220.

Bhattacharya G C and Yatheesh V 2015 Plate-tectonic evolution of the deep ocean basins adjoining the western continental margin of India - a proposed model for the early opening scenario; Petroleum Geoscience: Indian Contexts, Springer, pp. 1-61.

Biswas S K 1982 Rift basins in western margin of India and their hydrocarbon prospects with special reference to Kutch basin; Bull. Am. Assoc. Petrol. Geol. 66 14971513.

Biswas S K 1987 Regional tectonic framework, structure and evolution of the western marginal basins of India; Tectonophys. 135 307-327.

Biswas S K 1988 Structure of the western continental margin of India and related igneous activity; Geol. Soc. India Memoir 10 371-396.

Calvès G, Schwab A M, Huuse M, Clift P D, Gaina C, Jolley D, Tabrez A R and Inam A 2011 Seismic volcanostratigraphy of the western Indian rifted margin: The pre-Deccan igneous province; J. Geophys. Res. 116 (B1), https://doi. org/10.1029/2010JB000862.

Carmichael S M, Akhter S, Bennett J K, Fatimi M A, Hosein K, Jones R W, Longacre M B, Osborne M J and Tozer R S J 2009 Geology and hydrocarbon potential of the offshore Indus basin, Pakistan; Petrol. Geosci. 15 107-116.

Chaubey A K, Bhattacharya G C, Murty G P S, Srinivas K, Ramprasad T and Rao D G 1998 Early Tertiary seafloor spreading magnetic anomalies and paleo-propagators in the northern Arabian sea; Earth Planet. Sci. Lett. 154 $41-52$.

Chaubey A K, Dyment J, Bhattacharya G C, Royer J Y, Srinivas K and Yatheesh V 2002a Paleogene magnetic isochrons and palaeo-propagators in the Arabian and eastern Somali basins, northwest Indian Ocean; In: The tectonic and climatic evolution of the Arabian sea region (eds) Clift P D, Kroon D, Gaedicke C and Craig J, Geol. Soc. London, Spec. Publ. 195 71-85.

Chaubey A K, Rao D G, Srinivas K, Ramprasad T, Ramana M V and Subrahmanyam V 2002b Analyses of multichannel seismic reflection, gravity and magnetic data along a regional profile across the central-western continental margin of India; Mar. Geol. 182 303-323.

Collier J S, Sansom V, Ishizuka O, Taylor R N, Minshull T A and Whitmarsh R B 2008 Age of Seychelles-India break-up; Earth Planet. Sci. Lett. 272 264-277.

Corfield R I, Carmichael S, Bennett J, Akhter S, Fatimi M and Craig T 2010 Variability in the crustal structure of the 
west Indian continental margin in the northern Arabian sea; Petrol. Geosci. 16 257-265.

Courtillot V, Besse J, Vandamme D, Montigny R, Jaeger J J and Cappetta H 1986 Deccan flood basalts at the Cretaceous/Tertiary boundary?; Earth Planet. Sci. Lett. $80361-374$.

Devey C W and Stephens W E 1991 Tholeiitic dykes in the Seychelles and the original spatial extent of the Deccan; J. Geol. Soc. London 148 979-983.

Dyment J 1998 Evolution of the Carlsberg ridge between 60 and 45 Ma: Ridge propagation, spreading asymmetry, and the Deccan-reunion hotspot; J. Geophys. Res. 103 24067-24084

Kaila K L, Krishna V G and Mall D M 1981a Crustal structure along Mehmadabad-Billimora profile in the Cambay basin, India, from deep seismic soundings; Tectonophys. 76 99-130.

Kaila K L, Murty P R K, Rao V K and Kharetchko G E 1981b Crustal structure from deep seismic soundings along the Koyna II (Kelsi-Loni) profile in the Deccan trap area, India; Tectonophys. 73 365-384.

Kaila K L, Murty P R K, Mall D M, Dixit M M and Sarkar D 1987 Deep seismic soundings along Hirapur-Mandla profile, central India; Geophysics 89 399-404.

Kaila K L, Murty P R K and Mall D M 1989a The evolution of the Vindhyan basin vis-a-vis the NarmadaSon lineament, central India, from deep seismic soundings; Tectonophys. 162 277-289.

Kaila K L, Rao J B P, Rao P K, Rao N M, Krishna V G and Sridhar A R 1989b DSS studies over Deccan traps along the Thuadara-Sendhwa-Sindad Profile, across Narmada-Son lineament, India; In: Properties and processes of earth's lower crust (eds) Mereu R F, Mueller $\mathrm{S}$ and Fountain D M, Amer. Geophys. Union Geophys. Monograph 51 127-141.

Kaila K L, Tewari H C, Krishna V G, Dixit M M, Sarkar D and Reddy M S 1990 Deep seismic sounding studies in the north Cambay and Sanchor basins, India; Geophys. J. Int. 103 621-637.

Kaila K L and Krishna V G 1992 Deep seismic sounding studies in India and major discoveries; Curr. Sci. $62117-$ 154.

Krishna K S, Gopala Rao D and Sar D 2006 Nature of the crust in the Laxmi basin $\left(14^{\circ}-20^{\circ} \mathrm{N}\right)$, western continental margin of India; Tectonics, https://doi.org/10.1029/ 2004 TC001747.

Krishna V G 2004 Propagation of regional seismic phases in the Indian shield: constraints on crustal and upper mantle velocity models; Bull. Seismol. Soc. Am. 94 29-43.

Kumar P, Tewari H C and Khandekar G 2000 An anomalous high-velocity layer at shallow crustal depths in the Narmada zone, India; Geophys. J. Int. 142 95-107.

Mahadevan T M 1994 Deep continental structure of India: A review; Geol. Soc. India Memoir 28 569p.

Mahoney J J, Natland J H, White W M, Poreda R, Bloomer S H, Fisher R L and Baxter A N 1989 Isotopic and geochemical provinces of the western Indian Ocean spreading centers; J. Geophys. Res. 94 4033-4052.

Malod J A, Droz L, Kemal B M and Patriat P 1997 Early spreading and continental to oceanic basement transition beneath the Indus deep-sea fan: Northeastern Arabian sea; Mar. Geol. 141 221-235.
Mathur R B and Nair K R 1993 Exploration of the Bombay offshore basin; Proceedings of Second Seminar on Petroleum Basins of India, KDMIPE and ONGC 2 365396.

Miles P R and Roest W R 1993 Earliest sea-floor spreading magnetic anomalies in the north Arabian sea and the ocean-continent transition; Geophys. J. Int. 115 10251031.

Miles P R, Munschy M and Segoufin J 1998 Structure and early evolution of the Arabian sea and East Somali basin; Geophys. J. Int. 134 876-888.

Misra A A, Sinha N and Mukherjee S 2015 Repeat ridge jumps and micro-continent separation: Insights from NE Arabian sea; Mar. Petrol. Geol. 59 406-428.

Murti K V S, Prasad B N and Rawat G S 1981 Structure of continental margin off Bombay; Workshop on geological interpretation of geophysical data, Institute of Petroleum Exploration, Dehradun, India.

Murty A S N, Prasad B N, Rao P K and Sateesh S R T 2010 Delineation of subtrappean Mesozoic sediments in Deccan Syneclise, India, using travel-time inversion of seismic refraction and wide-angle reflection data; Pure Appl. Geophys. 167 233-251.

Naini B R and Talwani M 1983 Structural framework and the evolutionary history of the continental margin of western India; In: Studies in continental margin geology (eds) Watkins J S and Drake C L, Am. Assoc. Pet. Geol. Memoir 34 167-191.

Nair K M, Singh N K, Ram J, Gavarshetty C P and Muraleekrishanan B 1992 Stratigraphy and sedimentation of Bombay offshore basin; J. Geol. Soc. India 40 415-442.

Nair R R 1975 Nature and origin of small scale topographic prominences on the western continental shelf of India; Indian J. Mar. Sci. 4 25-29.

Nair N, Anand S P, Rajaram M and Rao P R 2015 A relook into the crustal architecture of Laxmi ridge, northeastern Arabian sea from geopotential data; J. Earth Syst. Sci. $124613-630$.

Norton I O and Sclater J G 1979 A model for the evolution of the Indian Ocean and the breakup of Gondwanaland; J. Geophys. Res. 84 6803-6830.

Pandey A and Pandey D K 2015 Mechanism of crustal extension in the Laxmi basin, Arabian sea; Geodesy Geodyn. 6(6) 409-422.

Pandey D K, Clift P D, Kulhanek D K, Andò S, Bendle J A P, Bratenkov S, Griffith E M, Gurumurthy G P, Hahn A, Iwai M, Khim B K, Kumar A, Kumar A G, Liddy H M, Lu H, Lyle M W, Mishra R, Radhakrishna T, Routledge C M, Saraswat R, Saxena R, Scardia G, Sharma G K, Singh A D, Steinke S, Suzuki K, Tauxe L, Tiwari M, Xu Z and Yu Z 2016 Site U1457; In: Arabian sea monsoon (eds) Pandey D K, Clift P D, Kulhanek D K and the expedition 355 scientists, Proceedings of the International Ocean Discovery Program 355, https://doi.org/10.14379/ iodp.proc.355.104.2016.

Pandey D K, Pandey A and Rajan S 2011 Offshore extension of Deccan Traps in Kachchh, central western India: Implications for geological sequestration studies; Nat. Resour. Res. 20(1) 33-43.

Pandey D, Singh S, Sinha M and MacGregor L 2009 Structural imaging of Mesozoic sediments of Kachchh, India, 
and their hydrocarbon prospects; Mar. Petrol. Geol. 26 1043-1050.

Pandey J and Dave A 1998 Stratigraphy of Indian petroliferous basins; XVI Indian Colloquium on Micropalaeontology and Stratigraphy, National Institute of Oceanography, Goa, India.

Parida G and Mishra Y K 1992 A late Paleocene-early Eocene fan delta in Bombay offshore basin; ONGC Bull. 29(2).

Pandey O P, Agrawal P K and Negi J G 1995 Lithospheric structure beneath Laxmi ridge and Late Cretaceous geodynamic events; Geo-Mar. Lett. 15 85-91.

Planke S 1994 Geophysical response of flood basalts from analysis of wire line logs: Ocean Drilling Program Site 642, Vøring volcanic margin; J. Geophys. Res. 999279 9296.

Planke S, Symonds P A, Alvestad E and Skogseid J 2000 Seismic volcanostratigraphy of large-volume basaltic extrusive complexes on rifted margins; J. Geophys. Res. $10519335-19351$.

Radha Krishna M, Verma R K and Purushotham A K 2002 Lithospheric structure below the eastern Arabian sea and adjoining west coast of India based on integrated analysis of gravity and seismic data; Mar. Geophys. Res. 23(1) $25-42$.

Ramana M V, Desa M A and Ramprasad T 2015 Reexamination of geophysical data off northwest India: Implications to the Late Cretaceous plate tectonics between India and Africa; Mar. Geol. 365 36-51.

Rao P and Wagle B G 1997 Geomorphology and surficial geology of the western continental shelf and upper slope of India: A review; Curr. Sci. 73 330-350.

Rao R P and Srivastava D C 1981 Seismic stratigraphy of west Indian offshore; Workshop on Geological interpretation of Geophysical Data, ONGC, Dehradun, pp. 1-9.

Rao R P and Talukdar S N 1980 Petroleum geology of Bombay High field, India. In: Giant oil and gas fields of the decade 1968-1978 (ed.) Halbouty M T, Am. Assoc. Pet. Geol. Memoir 30 487-506.

Rao T C S 1967 Seismic refraction measurements in the Gulf of Cambay and Kutch; Proc. Symp. Upper Mantle Proj., Geophys. Res. Board, NGRI, Hyderabad, pp. 342-347.

Rao T C S 1970 Seismic and magnetic surveys over the continental shelf off Konkan coast; Proc. Second Symp. Upper Mantle Proj., Geophys. Res. Board, NGRI, Hyderabad, pp. 59-72.

Raval U and Veeraswamy K 2003 India-Madagascar separation: Breakup along a pre-existing mobile belt and chipping of the craton; Gondwana Res. 6 467-485.

Reddy P R 2005 Crustal velocity structure of western India and its use in understanding intraplate seismicity; Curr. Sci. 88 1652-1657.

Richards M A, Duncan R A and Courtillot V E 1989 Flood basalts and hot-spot tracks: Plume heads and tails; Science 246 103-107.
Roychoudhury S C and Deshpande S V 1982 Regional distribution of carbonate facies, Bombay offshore region, India; Bull. Am. Assoc. Pet. Geol. 66 1483-1496.

Royer J Y, Chaubey A K, Dyment J, Bhattacharya G C, Srinivas K, Yatheesh V and Ramprasad T 2002 Paleogene plate tectonic evolution of the Arabian and eastern Somali basins; In: The tectonic and climatic evolution of the Arabian sea region (eds) Clift P D, Kroon D, Gaedicke C and Craig J, Geol. Soc. London, Spec. Publ. 195 7-23.

Sahay B 1978 Geology of Bombay High and adjoining structures; Proc. 7th Offshore Southeast Asia (SEAPEX) Conference, pp. 80-99.

Sahay B 1984 Analytical study of overpressured area in Bombay offshore basin; Southeast Asia Show, Society of Petroleum Engineers, pp. 4-41.

Senapati R B, Singh N K, Kumar A and Tikku C L 1993 Hydrocarbon prospect of Patan area, Patan-Sanchar Block, North Cambay basin India, India; ONGC Bull. $30(2)$.

Singh A P 1999 The deep crustal accretion beneath the Laxmi ridge in the northeastern Arabian sea: The plume model again; J. Geodyn. 27 609-622.

Sreejith K M, Chaubey A K, Mishra A, Kumar S and Rajawat A S 2016 Pseudofaults and associated seamounts in the conjugate Arabian and eastern Somali basins, NW Indian Ocean - New constraints from high-resolution satellite-derived gravity data; J. Asian Earth Sci. 131 $1-11$.

Storey M, Mahoney J J, Saunders A D, Duncan R A, Kelley S P and Coffin M F 1995 Timing of hot spot-related volcanism and the breakup of Madagascar and India; Science $267852-855$.

Talwani M and Reif C 1998 Laxmi ridge - A continental sliver in the Arabian sea; Mar. Geophys. Res. 20 259-271.

Tandon A N 1973 Average thickness of the Deccan traps between Bombay and Koyna from dispersion of shortperiod Love waves; Pure Appl. Geophys. 109 1693-1699.

Todal A and Eldholm O 1998 Continental margin off western India and Deccan large igneous province; Mar. Geophys. Res. 20 273-291.

Torsvik T H, Tucker R D, Ashwal L D, Eide E A, Rakotosolofo N A and Dewit M J 1998 Late Cretaceous magmatism in Madagascar: Paleomagnetic evidence for a stationary Marion hotspot; Earth Planet. Sci. Lett. 164 221-232.

Venkatesan T R, Pande K and Gopalan K 1993 Did Deccan volcanism pre-date the Cretaceous/Tertiary transition?; Earth Planet. Sci. Lett. 119 181-189.

White R and McKenzie D 1989 Magmatism at rift zones: The generation of volcanic continental margins and flood basalts; J. Geophys. Res. 94 7685-7729.

Yatheesh V, Bhattacharya G C and Dyment J 2009 Early oceanic opening off western India-Pakistan margin: The Gop basin revisited; Earth Planet. Sci. Lett. $\mathbf{2 8 4}$ 399-408. 